\title{
Relationship Between Physical School Climate and Teachers' Effectiveness in Senior Secondary Schools in Yobe State, Nigeria
}

\author{
Ahmed Chiroma Aminu \\ Modibbo Adama University of Technology Yola, Department of Science Education, \\ P.M.B 2076, Yola Adamawa State; Nigeria \\ Waziri Garba El-jajah* \\ Modibbo Adama University of Technology Yola, Department of Science Education, \\ P.M.B 2076, Yola Adamawa State; Nigeria
}

\begin{abstract}
This study investigated the relationship between physical school climate and teachers' effectiveness in senior secondary schools in Yobe State, Nigeria. This study adopted organic system theory propounded by Niskanem (1971).1 purpose, two research questions and 1 null hypothesis guided the study. The population was of the study was 5,322 subjects. The Sample size was 359 elements selected using Taro Yamane's method. Mean and standard deviation were used to analyze the research questions. linear regression analysis was used to test the hypothesis at 0.05 level of significance. Findings: This study revealed that a significant relationship exist between physical school climate and teachers' effectiveness in senior secondary schools in Yobe State, Nigeria.This study also established that Physical climate is moderate in Senior Secondary Schools in Yobe State as revealed by the mean score of 3.21 and teachers' effectiveness is also high in Senior Secondary Schools as revealed by the mean score of 4.13 Recommendation: Ade quate physical environment should be provided. Principals and teachers should ensure proper planning and maintainance of the physical environment and facilities in the school.
\end{abstract}

Keywords: Physical, School, Climate, Teachers and Effectiveness

DOI: $10.7176 / \mathrm{JEP} / 10-26-08$

Publication date:September $30^{\text {th }} 2019$

\section{Background of the Study}

The term teacher effectiveness and the instruments for its measurement have generated a lot of controversy in the world and hence there has been no consensus definition of teachers' effectiveness, because there is little or no agreement on what good teaching should be. It has been defined variously by researchers. Evans (2006) defined teacher's effectiveness as teachers' personalities, teacher-pupil interactions and teachers' impact on pupil's behaviour. The process and product aspects of teaching are well represented in these definitions. The processes of teaching bear a direct relationship to teachers' personalities and teacher-pupil interactions. . Evans (2006) described teachers' effectiveness as a kind of classroom assesment that occur between teachers and students resulting in an increase in students' knowledge. This refers to communication skills, use of praises, rewards and motivation during the teaching process.

Badau (2011) stressed that effective teacher must therefore stress the knowledge and skills needed to attain the educational goals and objectives and must be able to use that knowledge and those skills appropriately if these goals are to be achieved. Teacher effectiveness links teacher's competence and teacher performance with the accomplishment of the goals and objectives of the school. Jaafari, Karami and Soleimani (2012) argued that teachers with high effectiveness utilized the classroom efficiently, practice things that are associated with students' achievement and gain and enhance the feature of self-efficacy in their performance. Nurharani, NurZahira and NurShaminah (2013) stated that in cases where teachers are burdened with paperwork and administrative duties, teaching and learning process may be affected because teachers may have less time to achieve stated goals and objectives.

Uduak and Bassey (2015) opined that teachers effectiveness constitute a very vital component despite the remarkable advancement in technology in all areas of teaching and learning process through the production of instructional materials such as television, computer projector of various kinds. The teacher is still an indispensably significant factor for motivating and imparting knowledge to the learners at each level of education. The extent to which teachers achieve this important role of imparting knowledge is contingent on their effectiveness. Raza (2010) observed that teachers who have high intimacy with school members, know each other well and share personal issues with each other, who provide strong support for each other and are there for each other during difficult situations, support and encourage those teachers, are able to work with full enthusiasm and at the end become effective in their teaching job. As a result of a positive relationship, it is likely to contribute to positive climate. Badau (2016) believed that students who are assigned to one ineffective teacher after another have significantly lower achievement and learning than those who are assigned to a sequence of 
several highly effective teachers. Mohammed (2016) stated that the set of effectiveness a teacher has reflects in his skills and knowledge. Abilities and beliefs acquired during training may reflect on the academic achievement of their students'

Akiri (2013) stated that effective teachers who are still willing to serve so that they can contribute their wealth of experience to improve the system of education and effective teachers should produce students with higher academic performance while poor academic performance of students in Nigeria has been linked to ineffective teachers' in terms of accomplishing the teaching task, negative attitude to work and poor teaching habits which have been attributed to poor motivation. Akiri (2013) observed that conditions that would make for effective teaching resources, general conditions of infrastructure as well as instructional materials should be available to teachers in public secondary schools in Nigeria Kaur (2018) argued that effective teacher is an indispensable factor even in the best-equipped system of education. He who teaches effectively may pave the way for progressive and productive society. The effectiveness of a teacher can be well assessed by using the newly recognized classes of variables related to Teacher Effectiveness identified by Kaur (2018) as: (i) Process criterion (ii) Product criterion (iii) Presage criterion

(i) Process criterion: It involves the classroom interaction of the teacher with the pupils. It includes the behavior of the teacher, the reciprocate behavior of the pupils and rapport established between the two (resource link) in various academic activities.

(ii) Product criterion: It is very common and conventional way of appraising the standard of a process from the results or end products it incurs. Such criteria seek the extent to which the educational objectives have been achieved by the pupils. Whatever materials and resources may be applied and exercised by the teacher, his effectiveness is gauged from the progress and prosperity sustained by the learner. (iii) Presage criterion: It focuses on the academic background and personal characteristics of the teacher. The teacher's effectiveness is measured by his educational, professional and personal qualifications and experiences. Kindley (2016) asserted that teachers with a high sense of effectiveness may have high self-efficacy, typically have an easier time producing cognitive growth in their students and motivating them.

The physical school climate constitutes the environment as the outcome variable based on the assumption that teachers who are more satisfied with their classroom and environment provide higher-quality interactions with children and affect the behavior of students. Physical climate refers to the physical environment, level of upkeep, ambient noise, lighting, indoor air quality and/or thermal comfort of the school's physical building and its location within the community. Fabunmi and Oborah (2009) defined physical climate as the physical buildings which includes a playground, school size, equipment, laboratories, classrooms, feelings of safety, feelings of trust, respect for students and teachers and all materials used for instructions in the school to better students' academic achievement in school. According to Alimi (2007) physical climate consists of school building, playground, and outdoor equipment. It also includes classrooms, laboratories, workshops, library, resource rooms, assembly hall, furniture, administrative block, generator, dining hall and sometimes school garden that is used by members of the staff.

Alimi (2007) stated that physical climate can be identified as a major factor contributing to academic performance in the school system. According to Okeke (2013) the availability of physical structures in school determines the tone of a school and helps in the attainment of its goals and objectives. According to Adegbeson (2007) physical climate is the school facilities among the resources required in the realization of educational goals and objectives. Therefore, the process of achieving educational goals and objectives depends on school facilities planning as well as maintenance. Joseph and Philias (2011) have shown that the success of any educational endeavor rest on the availability of physical climate especially the school building and the availability of the school building and other plans contribute to good academic performance as they enhance effective teaching-learning activities. Joseph (2011) further stated that well sited school buildings with aesthetic conditions, playground, lavatory, etc. according to the scholar usually contribute to achieving higher educational attainment by the students. Loukas (2007) stated that physical climate includes: appearance of the school building and its classrooms, school size and ratio of students to teachers in the classroom, order and organization of classrooms in the school and availability of resources, safety and comfort in the school.

Muccai (2011) stated that an environment that is appropriate for education-oriented program is the one that contains sufficient buildings, equipment and materials for students to practice and master the essential content of learning. The most convenient and modern channel to achieve this for the school is to be equipped with proper teaching and learning facilities to make the students achieve their educational goals and objectives in the school. Cele (2010) stated that physical climate is the provision of equipment sufficient to support and accommodate multiple and diverse teaching programs and shouldincludes current technology that have a relationship with the environment and has a stimulating setting for both teachers and students in the school. Asiabaka (2008) confirmed that the classroom plays an important role in school where the students are brought together to learn and tolerate themselves. According to Mucai (2013) an environment that is appropriate for educational orientation program is the one that contains sufficient buildings, equipment and learning materials for students to 
practice and teachers' effectiveness to improve. Danjuma and Adeleye (2015) stated that adequate school facilities should be made with reference to the size and shapes of classroom which should be large and rectangular for 30/25 or 25 metres. United Nation Educational, Scientific and Cultural Organization (UNESCO, 2013) prescribed that there should be enough spaces in school buildings for offices, dormitories, classrooms, laboratories, seminar and conference rooms, and academic staff office and that each class should have a chalkboard, overhead projector, computers, and if possible tape recorders for effective teaching and learning in the school.

Danjuma and Adeleye (2015) confirmed that classroom could be well ventilated in order to be conducive for teaching and learning purposes which can enhance teacher's effectiveness. They further posited that to promote a proper atmosphere for effective teaching and learning the physical environment of the classroom must be equipped with desks, chairs, tables, space, instructional materials, lighting and ventilation as well as the latest information technology (ICT) equipment. Adeyemi (2010) noted that adequate school building is vital and physical resource items in the educational system which contribute to good academic performance as they enhance effective teaching and learning activities must be provided. Evans (2010) found that children attending schools with dilapidated classrooms and laboratories in conjunction with other risk factors have an adverse effect on their academic performance. Shaughuessy (2011) confirmed that noise level greatly affects teachers and students'performance, in fact, excessive noise causes dissatisfaction and stress in both the teacher and student. In view of this, classrooms with less external noise perform better than classrooms that have noisier environment.

Hull and Newport (2011).argued that physical classroom environment is important and sometimes has surprising effects on students' academic performance and teachers' effectiveness. Those classrooms' structural features include noise, lighting and everyday objects or teaching aids that facilitate students' learning and achievement. In considering changes to classroom environments, policymakers may want to consider both the inadequate facilities of many schools, as well as the symbolic aspects that may prevent students from achieving and teachers' effectiveness. Hull and Newport (2011) further posited that students exposed to more natural light (i.e., daylight) in their classrooms perform better than students exposed to less natural light.

Fisher, Godwin, and Seltman (2014) have demonstrated that the importance of physical climate which include the classroom and in the classroom wall décor and objects are displayed which influence teachers' effectiveness and shape student aspirations. Jones (2007) stressed that small classroom sizes and spaces have been linked to increased level of aggression among students .In this regard, overcrowded classrooms are also associated with decreased level of students' engagement and therefore decrease level of learning. Anyone that works in a classroom that is too hot or too cold would be uncomfortable. Jones (2007) asserted that temperature affect learning especially mathematics and science related subjects and makes teachers not effective.

Wyon (2004) stated that poor air quality in class environments could reduce students' performance.when air quality issues are experienced, students become very dissatisfied and teacher effectiveness reduced significantly. In a study by Schneider (2013), air quality was the top health complaint regarding school facilities with well over half of the teachers reporting it as a problem and another one third of the teachers suffer from a health problem because of poor school conditions. Rafiq et al (2016) demonstrated how important classroom dimensions are best for student performance, achieving air quality is not as simple as providing access to outdoor air since, in many cases, environmental toxins are present outside.

Shaughuessy (2011) further affirmed that indoor air quality is also a concern because poor air quality is a major contributor to absenteeism for students with asthma. This poor indoor air comes as the result of poor flooring materials, unpleasant paint, and environmental hazards which can negatively affect students' academic achievement and teachers' effectiveness. American students spend an average of 11,700 hours of their lives in a school building from kindergarten to 12th grade and college students typically spend at least another 400 classroom hours in post-secondary education buildings. Stevenson (2007) explained how the lighting conditions relate to students' academic performance, accounting for the roles of light where students with access to light in their classrooms achieve more academically than those without access to light in their classrooms. Planners and educators may develop strategies for individualized renovation and construction plans that support a particular school's mission' (Stevenson, 2007). Maxwell (2007) posited that school environments vary greatly; whereas some schools feel friendly, inviting, and supportive, others feel exclusionary,inwelcoming, and even unsafe. Maxwell (2007) further argued that classrooms with well-defined spaces in the physical environment corresponded with child competence and high academic achievement than classroom which has no defined space.

Wargocki and Wyon (2007) revealed that higher ventilation rates in classrooms make students interested in learning and less angry. When provided, more outdoor air and better air quality had a moderating impact on students' academic achievement. In a study by Monsuru (2014) found out that comfortable classroom temperature and smaller classes enhance teachers' effectiveness and provide opportunities for students to receive individual attention, ask more questions, participate fully in the discussion, reduce discipline problems and 
perform better than students in schools with larger classes. Clements-Croome (2013) stated that, the challenging aspect of air quality is that students may complain about odors, which serve as a good warning for bad air quality, this means that building schools and users of classrooms may bear in mind issues about ventilation in classrooms and schools. Winterbottom and Wilkins (2009) considered the luminous (bright color) effects of window openings and blinds on visual comfort in viewing projected media in schools and classrooms. They argued that the presence of a window predicts students' academic achievement with lighting, primarily by increasing satisfaction with views to the outdoors. In a similar vein, Brager and Baker (2009) stated that students with operable windows perform better than students with poor windows and poor light condition in their classrooms.

The feelings and attitudes that are elicited by a school's environment are the school climate. American Society of Heating, Refrigerating, and Air-Conditioning Engineers (ASHRAE, 2013). Schweiker, Brasche, Bischof, Hawighorst and Wagner (2013) argued that related illness and sick syndromes are often a direct result of inadequate air quality in classrooms and dormitorieswhich directly affects the academic performance of students and teacher effectiveness. Badau (2016) asserted that classroom environment and culture as well as the ways in which both students and learning are organized and managed increase teachers' effectiveness. The effective teacher manages the large number of relatively diverse students who occupy these classrooms within the environment efficiently. Badau (2016) found that teacher and students' perception of the physical aspects of their classrooms can either enhance or affect their performance and effectiveness. Badau (2016) further posited that the importance of physical environment, culture, and management of classrooms within the larger context of teachers' effectiveness is most clearly seen in the classroom with conducive temperature, light and air quality most importantly for students' academic achievement.

The National Union of Teachers (NUT, 2007) argued that the possibility of damage to hearing to groups of teachers to include anyone who works with particularly noisy groups of children, as well as those whose working in conditions with poor acoustic design. Noise generated by children often has a cumulative effect, as children shout to make themselves heard above the other noisy children. In the long term this can cause hearing impairment among teachers and pupils. High noise levels also lead to voice strain for teachers. NUT (2007) further argued that distraction and disturbance between groups using open-plain areas can be considerable unless remedial measures can be taken to improve acoustic separation between different areas. Carpeted floors can help, together with an acoustically absorbent ceiling. NUT (2007) believed that the sound insulation performance of a window is determined by the window frame, the sealing and the glazing. In existing buildings, secondary glazing can be installed as an alternative to replacing single glazing with double-glazing. The effectiveness of secondary glazing is determined by the thickness of the glass and the width of the air gap between the panes. It is also essential that the glazing in the window makes an airtight seal with its surrounding. Of equal importance is the need for an airtight seal between the perimeter of the window frame and the opening into which it is to be fixed, and when this is achieved, it can improve teacher's effectiveness.

Monsuru and Kamilu (2014) opined that class size affect both teacher effectiveness and students' academic performance and that the performance of students in large classes was very low compared to those students in smaller classes. In many cases, the quality of the learning environment was strongly correlated with pupils' academic achievement and teachers' effectiveness. Alabi (2014) stated that the basic facilities provided in each school should include enough students' accommodation, classrooms, health care facility, workshops, laboratories, administrative blocks, furniture, as well as vehicles. Ojoawo (2008) revealed that the class size was found to be negatively related to school academic performance. Monsuru, and Kamilu (2014) believed that the influence of class size on the quality of output in secondary schools revealed that schools having an average class size of 35 and below obtained better results in the secondary school certificate examination (SSCE) than schools having more than 35 students per class.

Monsuru (2014) observed that class size is an important factor with respect to teacher effectiveness and students'academic performance. There is a consensus among scholars that, student's achievement decreases as class size increases. Class size refers to educational tools that can be used to describe the average number of students per class in a school

\subsection{Statement of the Problem}

Education in all parts of Yobe State has suffered from years of neglect which made teachers not effective, compounded by inadequate attention to policy frameworks within the sector and acute shortages of infrastructure at all levels of education. According to Kajo (2011) the problems of ineffectiveness of teachers may be attributed to poor physical environment, and poor school working conditions. These observed problems if not taken care of will not only decline teachers' effectiveness but also affect the students' academic performance and may have a negative bearing on the development of the State. It is against this background that this study intends to investigate the relationship between physical school climate and teachers' effectiveness in senior secondary schools in Yobe State. Nigeria. 


\subsection{Purpose of the Study}

The specific objective of the study determined: the relationship between physical school climate and teachers' effectiveness in Senior Secondary Schools in Yobe State, Nigeria.

\section{I.1 The Research questions}

The following research questions were raised to guide this study:

(1) What is the extent of provision of physical facilities in senior secondary schools in Yobe State?

(2) What is the extent of teachers' effectiveness in Senior Secondary Schools in Yobe State?

\section{I.2 The hypothesis}

The following null hypotheses was formulated and tested at 0.05 level of significance.

$\mathrm{H}_{01}$ There is no significant relationship between physical school climate and teachers' effectiveness in Senior Secondary Schools in Yobe State

\section{METHODOLOGY}

\section{Research Design}

A correlation survey design was adopted for this study. The area of this study was Yobe State. It is located in the North - eastern part of Nigeria. Latitude $12.1871^{\circ} \mathrm{E}$ and Longitude $11.7068^{\circ} \mathrm{N}$. (National GeospatialIntelligence Agency, Bethesda, MD, USA 2004). The target population of this study was 3522 subjects comprising 48 Principals and 3474 teachers of Senior Secondary Schools within the three education zones of Yobe State. (Yobe State TeachingService Board, 2017). The sample size for this study was 359 subjects selected using Taro Yamane's method. The two instrument used were closed ended questionnaires with a five point Likert format response scale to generate data from the field. The research questions were answered using descriptive statistics (mean and standard deviation). The hypothesis was tested using linear regression at 0.05 level of significance.

\section{Findings}

Research question 1: What is the extent of provision of physical facilities in senior secondary schools in Yobe State?

Table 1: Mean scores and standard deviation of teachers' opinion on extent of physical facilities in Senior Secondary Schools inYobe State.

\begin{tabular}{|c|c|c|c|c|}
\hline $\mathbf{S} / \mathbf{N}$ & ITEM & N359 & Mean & Std. $\quad \mathbf{R}$ \\
\hline 1 & The condition of school buildings is standard & & 3.35 & $1.13758 \mathrm{M}$ \\
\hline 2 & Laboratories in the school are equipped for instruction & & 3.12 & $.89749 \mathrm{M}$ \\
\hline 3 & The school playground is often used by teachers & & 2.97 & $1.08430 \mathrm{M}$ \\
\hline 4 & The school library is regularly used by teachers & & 3.02 & $1.22375 \mathrm{M}$ \\
\hline 5 & Class size are large for teachers in the school & & 3.29 & $1.47686 \mathrm{M}$ \\
\hline 6 & Class size are small for instruction in the school & & 2.53 & $1.16976 \mathrm{H}$ \\
\hline 7 & Classrooms are well brightened by sunlight in the school & & 3.31 & $1.28275 \mathrm{M}$ \\
\hline 8 & The chalkboard surface is smooth in this school & & 3.16 & $1.37722 \mathrm{M}$ \\
\hline 9 & The school environment is safe for instruction & & 3.28 & $1.36368 \mathrm{M}$ \\
\hline \multirow[t]{2}{*}{10} & Classrooms are tidy in the school & & 3.04 & $1.26402 \mathrm{M}$ \\
\hline & GRAND MEAN & & 3.21 & \\
\hline
\end{tabular}

Key: VHE $=$ Very high extent, HE $=$ High extent, $\mathrm{ME}=$ Moderate extent, $\mathrm{LE}=$ Low extent and VLE $=$ Very low extent and $\mathrm{R}=$ Remarks

Table 1 shows the mean and standard deviation of respondents' opinion on the extent of provision of physical facilities in Senior Secondary Schools in Yobe State. A grand mean of 3.2112 indicates that the physical facilities are moderately provided. 
Research question 2: What is the extent of teachers' effectiveness in Senior Secondary Schools in Yobe State?

Table 2: Mean and standard deviation of principals' opinion on the extent of teachers'effectiveness in senior secondary schools in Yobe State.

\begin{tabular}{|c|c|c|c|c|c|}
\hline $\mathbf{S} / \mathbf{N}$ & ITEM & N359 & Mean & $\begin{array}{l}\text { SD } \\
\text { REMARK }\end{array}$ & \\
\hline 1 & Standard classroom enhances the teachers' teaching delivery & 359 & 3.52 & 0.1 .16 & $\mathrm{H}$ \\
\hline 2 & $\begin{array}{l}\text { Equipped laboratory facilitates teachers' practical lesson } \\
\text { presentation }\end{array}$ & 359 & 4.10 & $0 . .952$ & $\mathrm{H}$ \\
\hline 3 & $\begin{array}{l}\text { School playground enhances teachers' participation in extra- } \\
\text { curricular activities }\end{array}$ & 359 & 4.20 & $0, .989$ & $\mathrm{H}$ \\
\hline 4 & School library facilitates teacher' new discovery & 359 & 3.96 & $0 . .968$ & $\mathrm{H}$ \\
\hline 5 & Ventilated classroom promotes the teachers' teaching delivery & 259 & 4.08 & $0 . .986$ & $\mathrm{H}$ \\
\hline 6 & School staff room facilitates teachers' update school records & 359 & 3.96 & $0 . .570$ & $\mathrm{H}$ \\
\hline 7 & Brightened classroom enhances teachers' interest in teaching & 359 & 4.48 & $0 . .504$ & $\mathrm{H}$ \\
\hline 8 & Smooth chalkboard surface teachers' writing skill & 359 & 3.90 & $0 . .994$ & $\mathrm{H}$ \\
\hline 9 & $\begin{array}{l}\text { Safe school environment facilitates teachers' participate in } \\
\text { school extra-curricular activities }\end{array}$ & 50 & 4.04 & $0 . .727$ & $\mathrm{H}$ \\
\hline 10 & $\begin{array}{l}\text { Tidy classroom enhances the teachers' classroom management } \\
\text { GRANT MEAN }\end{array}$ & 50 & $\begin{array}{l}3.90 \\
4.13 \\
\end{array}$ & $0 . .814$ & $\begin{array}{c}\mathrm{H} \\
\mathrm{HE}\end{array}$ \\
\hline
\end{tabular}

Key: $\mathrm{VHE}=$ Very high extent, $\mathrm{HE}=$ High extent, $\mathrm{ME}=$ Moderate extent, $\mathrm{LE}=\mathrm{Low}$ extent and $\mathrm{VLE}=\mathrm{Very}$ low extentand $\mathrm{R}=$ Remarks

Table 2 above shows the mean and standard deviation of Principals' opinion on the extent of teachers' effectiveness in Senior Secondary Schools in Yobe State. A grand mean of 4.13 indicates that the teachers' effectiveness is high in Senior Secondary Schools

The hypotheses was tested using regression analysis at 0.05 level of significance

H01:There is no significant relationship between schools' physical climate and teachers' effectiveness in Senior Secondary Schools in Yobe State.

TABLE 3: Summary of ANOVA of Schools' Physical Climate and Teachers' Effectiveness.

\begin{tabular}{|c|c|c|c|c|c|c|}
\hline Model & & Sum of Squares & Df & Mean Square & $\mathrm{F}$ & Sig. \\
\hline \multirow[t]{3}{*}{1} & Regression & 6.154 & 1 & 6.154 & 12.775 & $.001^{\mathrm{b}}$ \\
\hline & Residual & 24.566 & 51 & .482 & & \\
\hline & Total & 30.720 & 52 & & & \\
\hline \multicolumn{7}{|c|}{$\mathrm{p}>0.05$} \\
\hline \multirow{3}{*}{\multicolumn{7}{|c|}{$\begin{array}{l}\text { a. Dependent Variable: Teachers' effectiveness } \\
\text { b. Predictors: (Constant), Physical climate }\end{array}$}} \\
\hline & & & & & & \\
\hline & & & & & & \\
\hline \multirow{5}{*}{\multicolumn{7}{|c|}{$\begin{array}{l}\text { Linear regression analysis was conducted to test whether any significant relationship exists between schools' } \\
\text { physical climate and teachers' effectiveness. The results show that there is a statistically significant relationship } \\
\text { between schools' physical climate and teachers' effectiveness, F }(1,52)=12.775, p=0.001 \text {. Therefore, the null } \\
\text { hypothesis was rejected since the p - value }(0.001) \text { is less than } 0.05 \text { level of significance. } \\
\text { Table 6: Model Summary }\end{array}$}} \\
\hline & & & & & & \\
\hline & & & & & & \\
\hline & & & & & & \\
\hline & & & & & & \\
\hline \multirow[t]{2}{*}{ Model } & $\mathrm{R}$ & R Square & \multirow{2}{*}{\multicolumn{2}{|c|}{ Adjusted R Square }} & Std. & of the \\
\hline & & & & & Esti1 & \\
\hline 1 & $.448^{a}$ & .200 & \multicolumn{2}{|c|}{.185} & .69404 & \\
\hline
\end{tabular}

a. Predictors: (Constant), Physical climate

The result in Table 3 shows how the independent variable explains the variance in the dependent variable.

The result shows that physical climate and teachers' effectiveness were found to have a moderate positive relationship which is indicated by $\mathrm{r}$ value $=0.448$.

\section{Findings of the study}

The following are the findings of the study:

1. Physical climate and teachers' effectiveness were found to have statistically moderate positive relationship in Senior Secondary Schools in Yobe State, $(r$ value $=0.599)$

\section{Discussion}

The result in Table 3 shows how the independent variable explains the variance in the dependent variable. The result shows that physical climate and teachers' effectiveness were found to have a moderate positive relationship ( $r$ value $=0.448$ ). This study is in line with study carried out by Raza (2013) who found out that there is significant positive relationship when the school working environment is conducive for the teachers' and 
will increase their commitment towards school activities. This study also is in line with the finding from Yusuf (2010) who found out that there was a significant relationship between physical environment and teachers' productivity and students' achievement in senior secondary schools. This study also is contrary to finding from Joseph and Philias (2011) that there is no significant difference between school facilities and academic achievement of secondary school agricultural science in ekiti state, nigeria

\section{Conclusion}

1. Physical climate is moderately in Senior Secondary Schools in Yobe State as revealed by the mean score of 3.21 .

2. Teachers' effectiveness is high in Senior Secondary Schools in Yobe State as revealed by the mean score of 4.13

\section{Recommendation}

1. Government should adequately provide sufficient physical climate to all Senior Secondary Schools in Yobe State.

2. Teachers' should use the school environment efficiently in the schools

\section{REFERENCES}

Adegbeson S. O. (2007) Adequacy of School Facilities in Nigeria Vocational and Technical Colleges: Nigerian Journal of Educational Administration and Planing. 7 (2),169-177.

Adeyemi ,T.O. (2010) The school library and students' learning outcomes in secondary schools in Ekiti State, Nigeria.Asian Journal of Business Management 2 (1), 1-8,

Akiri A, A(2013). Effects of teachers' effectiveness on students' academic performance in Public Secondary Schools; Delta State - Nigeria. Journal of Educational and Social Research MCSER Publishing, Rome-Italy 3 (3), 105-125.

Alabi, B.O (2014) Quality assessment of school facilities in Lagos State.12 (6), 20-38. Retrieved from lasusterg.okebsf..org/author/admin...

Alimi O, S, (2007). Physical plant mantainance, practice in the public secondary school in Akoko Zonal Education Area of Ondo State .Efe Journal of Education and Practice 4 (13), 73-78.

American Society of Heating Refrigerating and Air-Conditioning Engineers, (ASHRAE. 2013).Ventilation for acceptable indoor air quality Atlanta: ASHRAE. Inc.[ASHRAE], US Green Building Council, \&the Chartered Institution of Building.

Asiabaka, I. P. (2008).The need for effective facility management in schools in Nigeria. New York: Science Journal 1(2): 10-21.

Asiyai, R. I. (2012). Assessing school facilities in public secondary schools in Delta State, Nigeria . An International Multidisciplinary Journal, Ethiopia $6(2), 54$

Badau, K. M. (2011). Assessment of secondary school teacher effectiveness in the classroom in Adamawa and Taraba States of Nigeria, ATBU Journal of Technology and Educational Research 4 (3), 68-73.

Badau, K. M. (2016). Teacher's classroom management practices for increasing effectiveness in climate change in Nigeria. Advances in Social Sciences Research Journal, Education, United Kingdom 433 (1), 43-50.

Brager, G, \& Baker, L. (2009). Occupant satisfaction in mixed-mode buildings.Journal of Building Research and Information, 3 (7), 369-380.

Buchanan, E, (2013) A positive school climate and measuring the impact.Retrieved from www.wholechildeducation.org.

Cele Pilot Project (2010) On Strategic Investment Planing for Educational Infrastructure with the Euopean Investment Planing Bank.Workshop project updated in B.O. quality Assessment of school facilities in lagos State. Retrieved from Issusterg.okebsf./org/author/admin/.../12/06/2018.

Clemen.A .M. L (2016) SMCC Higher Education Research Journal 3 (2), 244- 246- $\cdot$ Retrieved from http://orcid.org/

Clements-Croome, D.(2013).Environmental health and well-being in buildings. In D. J. Clements-Croome (Ed.), intelligent buildings (2). 43-60 London: ICE Publishing.

Danjuma,T. T and Adeleye, M. O.(2015) The effect of the availability and uterlization of laboratory apparatus in the teaching of physics .KaruL.G.E.A,Nigeria. Research Journal of Educational Studies and Review, 1 (5), 118-122.

Directorate for planning research and statistics, Yobe State Teaching Searvice Board Damaturu(2017). Data on schools teachers and Students. Ministry of Education Damaturu, Yobe State.

Evans, E. D. (2006). Transition to teaching. New York. Holt, Rinehart Winston

Evans,G.W, (2010) The ecological context of stuidents' achievements. Journal of Environmental Psychology.3(30), 239-244. 
Fisher, A. Godwin, K., and Seltman, H. (2014). Visual environment, attention allocation, and learning in young children: When too much of a good thing may be bad. Psychological Science, 25 (10), 1362-1370.

Hull, J., and Newport, M. (2011).time in school: how does the U.S. compare? Center for Public Education.Retrieved fromhttp://centerforpubliceducation.org/Main-Menu/Organizing-aschool/.

Jaafari a1. P, karami, S b and Soleimani, N (2012) The relationship among organizational climate, organizationa Learning Teachers Self - Efficiency.Tehran, IRAN.Procedia - Social and Behavioral Sciences 47, 2212 2218

Jones S, E, Axelrad R, and Wattigney W, A(2007).Healthy and safe school environment .Journal of School Health7(1), $77-80$.

Joseph O, and Philias O, Y (2011) School facilities and academic achievement of secondary school agricultural science in ekiti state, Nigeria. Asian Social Science Vol. 7, No. 7

Kaur, H. (2018). A study of teacher effectiveness in relation to organizational climate. International Journal of Engineering Science, 4, (8).16783 - 16784..

Kindley P, (2016).The relationships between school climate, teacher self-efficacy, and teacher beliefs.Unpublished Phd Dissertation Presented in Liberty University, Lynchburg, Virginia, USA

Loukas A. (2007) High-quality school climate as advantageous for all students and particularly beneficial for atrisk students.leadership compass, 5 (1), 1-3.

Makewa, L. N., Role, E., Role, J., \&Yegoh, E. (2011). School climate and academic performance in high and low achieving schools: Nandi Central District, Kenya. International Journal of Scientific Research in Education, 4(2), 93-104.

Maxwell, L. E. (2007).: The role of the physical Luminance in European offices to investigate its dependence on outdoor Indoor Air. 14 (7), 92-101.

Maxwell, L. E. (2007).: The role of the physical Luminance in European offices to investigate its dependence on outdoor Indoor Air. 14(7), 92-101.

Mohammed A. A. (2016). teachers' laboratory competence as a predictor of secondary school biology students' academic achievement in Adamawa State, Nigeria. Unpublished M. Tech (Ed) Thesis in the Department of Science Education Modibbo Adama University of Technology, Yola.

Monsuru, M. B \&Kamilu M. O (2014) Class size and school climate as correlates of secondary school students' scholastic achievement in Itesiwaju Local Government Area of Oyo State, Nigeria. Global Journal of Human-Social Science: G Linguistics \& Education 14 (3) 15-17.

Mucai. E.W.(2013) Availability and utilization of educational resources in influencing students performance in secondary schools in MbeereSourth ,Embu County, Kenya.Unpublished M.ED Thesis, Kenyatta University, Kenya

Niskanem.I (1971).organic system theory. Retrieved from://www.businessballs.com. 01/01/2017.

NurharaniS ,NurZahira S \&NurShaminah M. K (2013).The impact of organizational climate on teachers' job performance, Journal of Educational Research, 2 (1) 71-80.

Oborah, M. U. (2009) Improving management of school organizational climate of secondary schools in Kogi State, An unpublished master's thesis in the Department of Educational Foundations University of Nigeria.

Okeke, F. N.(2013).Management of facilities in the classroom.Journal of Emerging Trends in Educational Research and Policy Studies, 4(1), 100-104.

Rafiq, M., Aajiz, N. M., Wahid, F. E.,Rahman, A, Mand, R., \& Khan, A. (2016). The impact of school environment on the performance of students of public high schools a 'Khyber Pakhtunkhwa Pakistan.

Raza, S.A. \& Shah Arid, P.M.A. (2010).Impact of organizational climate on performance of college teachers In Punjab.Journal of College Teaching \& Learning, 3 (2), 129-147.

Sackney, L (2007). Enhancing school learning climate.Retrieved from http://saskschoolboards.ca/research/school_improvement/180.htm.1/3/2017.

Schneider, M. (2013).Linking school working conditions to teacher satisfaction and success. Washington: National Clearinghouse for Educational Facilities.

Schweiker, M., Brasche, S., Bischof, W., Hawighorst, M., \& Wagner, A. (2013). Explaining the individual processes leading to adaptive comfort and psychological reactions to thermal stimuli. Journal of Building Physics, 36 (4), 438-463.

Shaughnessy U, Moschandreas D. and Shaughnessy R, R (2011) Association between Substandard Classroom Ventilation Rate and Students Academic achievement. Journal of Indoor Air. 21 (1), 121-131.

Stevenson, K R 2007, 'Educational trends shaping school planning and design:, national clearinghouse for educational facilities, Washington DC accessed online on 17/05/07 $<\mathrm{http}$ :/www.edfacilities.org/pubs $>$.

The National Union of Teachers' (2005) Keep the noise down. Hamilton House, MabledonPlce,London WC1HGBD.www.vhpc.co.uk.

Uduak E, I and Bassey E, G (2015) Principals' supervisory techniques and teachers' job performance in 
secondary schools in Ikom Education Zone, Cross River State, Nigeria. British Journal of Education 3 (6), 31-40. Retrieved from www.eajournals.org.

United Nation Educational, Scientific and Cultural Organisation (UNESCO, 2013) Guide book for planing education in emergenciea and reconstruction / peris international institute for educational planing. Retrieved from http//www.iiep.unesco.org/.../...

Wargocki, P., \&Wyon, D. P. (2007). The effects of outdoor air supply rate and supply air filter condition in classrooms on the performance of schoolwork by children (RP-1257). HVAC\&R Research, 13 (2), 165-191.

Winterbottom, M., \& Wilkins, A. (2009). Lighting and discomfort in the classroom. Journal of Environmental Psychology, 29 (1), 63-75.

Wyon, D. P. (2004).The effects of indoor air quality on performance and productivity. Indoor Air, 14 (7), $92-$ 101. 